\title{
The effects of knowledge sharing, social capital and innovation on marketing performance
}

\author{
Made Setini $^{a^{*}}$, Ni Nyoman Kerti Yasa ${ }^{\mathrm{b}}$, I Wayan Gede Supartha ${ }^{\mathrm{b}}$ and I Gusti Ayu Ketut Giantaric
}

\author{
${ }^{a}$ Doctoral Program of Management, Faculty of Economics and Business, Udayana University, Denpasar, Bali, Indonesia \\ ${ }^{b}$ Professor, Department of Management, Faculty of Economics and Business, Udayana University, Denpasar, Bali, Indonesia \\ ${ }^{c}$ Lecturer, Department of Management, Faculty of Economics and Business, Udayana University, Denpasar, Bali, Indonesia

\section{H R O N I C L E}

\section{A B S T R A C T}

Article history:

Received: March 13, 2021

Received in revised format: April

10,2021

Accepted: June 14, 2021

Available online: June 14, 2021

Keywords:

Social Capital

Knowledge Sharing

Innovation

Marketing Performance

Women Entrepreneurs

\begin{abstract}
Women entrepreneurs and the informal sector are looking for footholds in the COVID-19 pandemic, which will lead women to develop creative businesses. This study examines the role of sharing knowledge and innovation in addressing gaps in social capital and marketing performance. Purposive sampling is used in the technique sample with 229 samples and Structural Equation Modeling (SEM-PLS) analysis techniques with SmartPLS is used for processing applications. The results show that social capital has a positive effect on the business performance of women entrepreneurs in Bali, Indonesia. The knowledge-sharing variable can be a mediator in the relationship between social capital and performance, and social capital has a significant positive effect on innovation, but innovation does not have a positive effect on marketing performance and knowledge sharing. In the end, women entrepreneurs will use knowledge sharing to create various innovations to meet market demand. However, opportunities for women entrepreneurs are very limited on capital due to the lack of guaranteed capital, and a lack of entrepreneurial skills in the era of technology, market access, bureaucracy, and legal matters. In addition, managerial skills, access to information technology, and the perspective that men should excel in Balinese culture and customs, limit business for women entrepreneurs.
\end{abstract}

C) 2021 by the authors; licensee Growing Science, Canada.

\section{Introduction}

The informal small business sector in Indonesia itself has proven to be resilient and tends to develop in the face of the global economic crisis in 1998 (Susilo, 2016). Women mostly choose the informal sector because of the flexibility of time they can take, said Sri Mulyani, the Minister of Finance during the "Inspiring Women event" in Jakarta. The subject of women entrepreneurs has been debated for decades to be predictors of entrepreneurship (Lee \& Kim, 2019; Dean et al., 2019; Neumeyer et al., 2018). Women entrepreneurs in Indonesia have supported the country's economic progress and prosperity, and especially during the 1998 financial crisis when women's entrepreneurship began to emerge (Kusumawardani et al., 2020). The emergence of women's micro-, small- and medium-sized enterprises (MSMEs) in the culinary informal sector has contributed a lot to the development of a country, especially in developing countries (Mintah \& Darkwah, 2018). The informal sector in Bali is dominated by women because of the time flexibility it allows. The women entrepreneurs in the informal culinary sector said that customers in the last two years felt that they had started to decrease, the products sold were not selling in the market, and the income they earned had fallen. In view of this phenomenon, it is necessary to think about the steps that need to be taken so that the marketing performance of women-run MSME in the informal culinary sector can survive and grow. Performance improvement can involve culinary marketing to retain consumers, increase the volume of sales, and market expansion (Murphy et al., 2016). Increased marketing performance can be influenced by social capital because developing networks and strengthening relationships will create trust, a norm in equalizing business vision and mission (Kim \& Shim, 2018; Afriyie et al., 2019). Several studies have shared the same view that the success of informal small businesses, including

* Corresponding author.

E-mail address: made.setini@student.unud.ac.id (M. Setini)

(C) 2021 by the authors; licensee Growing Science, Canada. doi: $10.5267 /$ j.ijdns.2021.6.008 
in the scope of marketing, is influenced by social capital and innovation (Torres et al., 2019; Kebede, 2018). Social capital is a fundamental resource for women to become entrepreneurs and makes their marketing patterns easier to do (Nguyen et al., 2019). Social capital is not able to increase sales and produce good marketing performance (Subramony et al., 2018; Farida, 2017). The research described above has gap on the influence of social capital on marketing performance, and the adoption of innovation does not always provide positive results on improving marketing performance. Another variable is needed to address the research gap, which is knowledge sharing (Akhavan et al., 2015). Sharing knowledge leads to learning about female entrepreneurship and being able to provide creative innovation ideas in line with research (Agyapong et al., 2017)

\section{Literature Review}

\subsection{Theory of the Social Capital}

The theory of social capital was first systematically introduced by Nahapiet and Ghoshal (1998). The basic definition introduced is that social capital is a resource inherent in social relations. The application of social capital theory is aimed at understanding social bonds, social interactions, trust, and reciprocity (Nahapiet \& Ghoshal, 1998; Sanchez-Famosoa et al., 2019). Dastourian et al. (2017) state that social capital is an order of values embedded in social networks in a relationship between individuals or groups in an organization. Structural social capital refers to the overall pattern of connections in a social system that is formed by the property, personal and commercial relationships in terms of density, centrality, connectivity, hierarchy, and network configuration according to Lefebvre et al. (2016). Relationship social capital refers to assets that are created and utilized through relationships based on respect, friendship, trust and hope (Coleman, 1988; Kim \& Shim, 2018). According to Martínez Pérez et al. (2016), the core of trust between humans is three things: (1) the social relationship between two or more people; (2) the expectations contained in the relationship; (3) social interactions that enable these relationships and expectations to be realized. Social capital cognitive refers to shared representation by adhering to norms in interpreting the vision and mission between parties in a common goal according (García-Villaverde et al., 2018; Nahapiet \& Ghoshal, 1998). Norms are a form of social obligation, which makes both parties feel benefitting, in this way the exchange relationship is obtained.

\subsection{Theory of the Knowledge Base}

This process is summarized in a model, namely, the Socialization, Externalization, Combination, and Internalization model (SECI) (Nonaka \& Takaeuchi, 1995). The internalization process is a transfer from explicit knowledge to tacit knowledge where knowledge is obtained from learning by doing the process. The SECI process embodies the creation of knowledge as a valuable asset for the organization to manage. Knowledge sharing refers to activities where knowledge is shared or exchanged in various forms from individuals, groups, or organizations to others (Acosta et al., 2018). Knowledge is information that has been analyzed and organized so that it can be understood and used to solve problems and make decisions (Mohajan, 2019). Based on the origin of knowledge and its development (Boadu et al., 2018; Rumanti et al., 2016), knowledge management is divided into two, namely, tacit, and explicit. Basically, knowledge tacit is personal, developed through experiences that are difficult to formulate and communicate. Explicit knowledge makes this easier because the knowledge obtained is in the form of writing or seminars. Knowledge sharing creates opportunities to take advantage of existing resources and influences the benefits of networks that can be mobilized, acting as a transmission channel for information, and providing access to resources (Tata \& Prasad, 2015).

\subsection{Innovation}

Innovation has found a more important role in the evolution of social and economic structures than the modern economy is considered in some studies to be an innovation-based economy (Zhou et al., 2019; Aujirpongpan \& Hareebin, 2020). Innovation is defined as the extent to which an organization offers new or better products and services to the market (Acosta et al., 2018). Innovation means a product, idea, information technology, institutions, behavior, values, and new practices, in other words, innovation is the modification or discovery of ideas for continuous improvement and development to meet customer needs (Sanchez-Famosoa et al., 2019). To achieve continuous innovation, managers need to focus, not only on products, technology, and processes, but also on organizational culture, norms, and values that govern the organization (Srisathan et al., 2020; Muafi, 2020)

\subsection{Marketing Performance}

Performance is a description of the level of achievement of implementation, a program of activities or policies in realizing the goals, objectives, vision, and mission of the organization as outlined in the strategic planning of an organization (Kittikunchotiwut, 2020). Marketing performance is a company's effort to identify and meet consumer needs and tastes (Leal-Rodríguez \& Albort-Morant, 2016), whereas according to Smith (2017), marketing performance is a company's efforts to identify and fulfill needs and consumer taste, can be viewed as a concept used in measuring the extent to which market performance can be achieved by a product that has been produced. 
One of the anchors of company performance is marketing performance, which means that good marketing performance will create good company performance too (Lestari et al., 2020). Marketing performance is a concept for measuring the market performance of a product. For Zhou et al. (2019), every company has an interest in knowing the market performance of the products offered is, and what is the reflection of the success of their business in the business world (Adi et al., 2021).

\subsection{Informal Sector Women Entrepreneurs}

Various informal sectors have crystallized significantly into seven dominant schools of thought, namely, dualist, structuralism, legalist, rational choice, rational-legal theory, recession-driven theory, and labor-supply theory regarding their nature and composition (Siqueira et al., 2016). In several developed countries such as the United States and Japan as well as in several new countries such as Taiwan and South Korea, the economic strength comes from the support of small businesses, and a large part of the workforce is absorbed in the small-scale business sector. Various weaknesses faced by small businesses, especially women's small businesses, indicate low or weak company performance. Akintimehin et al. (2019) state that the low performance of small businesses in developing countries is influenced by factors such as social capital, location, information, and human resources, and knowledge plays a role in influencing the performance of small businesses. Rajapathirana and Hui (2018) posit that marketing performance is largely determined by factors of human resources, marketing, production, working capital, wage systems, and work culture.

\subsection{Relationship between Variables and Conceptual Frameworks}

MSMEs are needed, not only for the survival of the organization, but also for improving business performance, and social capital which is divided into two types, namely, internal and external, is very important for women-run MSMEs in the informal culinary sector because they complement each other to ensure efficient business performance (Akintimehin et al., 2019). External social capital is social capital that has links to businesses such as loyal customers, suppliers, and professional associations so that the benefits of this external social capital giving market authority will have a positive impact on sales revenue and the level of informal profitability of business firms (Putra et al., 2020). The social networks, bonds, and trust that women entrepreneurs share and rely on during their business operations are important investments in creating customer loyalty and improving marketing performance (Muniady et al., 2015; Tata \& Prasad, 2015). Social capital is very important in the process of knowledge transformation and exploitation, namely, the ability to combine existing and newly-assimilated knowledge and apply it to company operations and strategies (Allameh, 2018; van Dijk et al., 2016; Lee, et al., 2015; Kim \& Shim, 2018). Good interpersonal relationships help individuals feel psychologically secure; this process stimulates creativity, and social capital also allows people to seek advice to solve problems and generate new insights (SanchezFamosoa et al., 2019; Farida, 2017; Dastourian et al., 2017). Trust in social capital provides safer access to a heterogeneous set of resources that can drive innovation (Rass et al., 2013; Moqbel \& Nah, 2017; Nguyen et al., 2019). The transfer of information and technology from one corporate department to another can drive the evolution of discoveries as it smooths out the specialization of knowledge resource integration (Dhir et al., 2021). Lee et al. (2016) show that the quality of knowledge sharing positively affects the manufacturing performance of companies in China. Knowledge sharing provides information and provides access to external resources. In an evolving and unpredictable social environment, innovation is considered by many to be the driving force for strategic competitiveness and sustainable value in Ghana; innovation across MSMEs is necessary, not only for organizational survival, but also for enhancing business performance (Gemünden et al., 2018), and brings various aspects of innovation to light to understand its relationship with firm performance (Bolisani et al., 2018; Acosta et al., 2018).

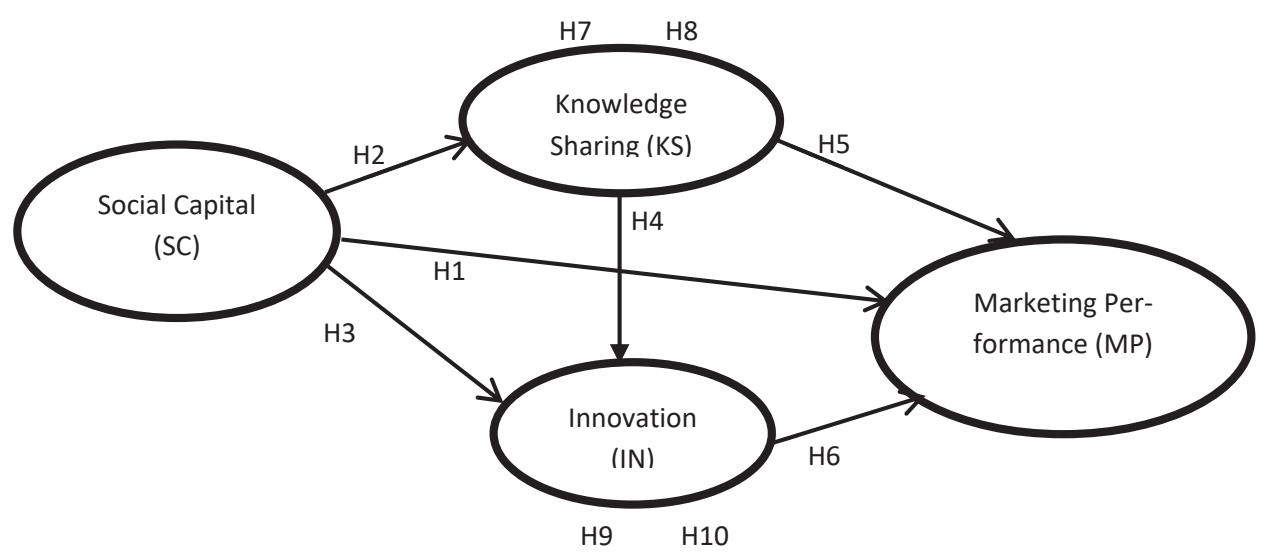

Fig. 1. Model Framework

$\mathbf{H}_{1}$ : Social capital has a positive and significant effect on marketing performance. 
$\mathbf{H}_{2}$ : Social capital has a positive and significant effect on knowledge sharing.

H3: Social capital has a positive and significant effect on innovation.

$\mathbf{H}_{4}$ : Knowledge sharing has a positive and significant effect on innovation.

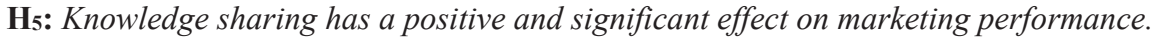

H6: Innovation has a positive and significant effect on marketing performance.

$\mathbf{H}_{7}$ : Knowledge sharing can mediate the effect of social capital on innovation.

$\mathbf{H}_{8}$ : Knowledge sharing can mediate the effect of social capital on marketing performance.

H9: Innovation can mediate the effect of knowledge sharing on marketing performance.

$\mathbf{H}_{10}$ : Innovation can mediate the effect of social capital on marketing performance.

\section{Method}

The research uses the quantitative method, borrowing from principles of positivism. The location of this research was carried out at MSME run by women in the informal culinary sector in Bali. Data collection via structured questionnaire questions are distributed online. Samples were taken from the population of women in the informal sector of the culinary sector in Bali, and the respondents were the business owners themselves. The sampling technique used purposive sampling. The number of samples used was 5 to 10 multiplied by the indicator so that the sample of 229 was quite representative of women entrepreneurs in Bali. Structured data collection techniques in this study using a pre-prepared online questionnaire, with a Likert scale to measure social capital, innovation, knowledge sharing, and performance variables; all respondents were given a questionnaire containing closed statements. Social capital is measured by a semantic differential approach on a scale of one to five, social capital in this study, namely, the women-run MSMEs in the informal culinary sector in Bali citing measurements carried out by (Burt, 1995; Muniady et al., 2015; Kim \& Shim; 2018). Sharing knowledge can contribute to reduced production costs, faster completion of development projects, improved decision-making and coordination on results, ability to innovate, and increased sales or revenue from new products and services (Boadu et al., 2018; Rumanti et al.., 2018; Salehzadeh et al., 2017; Allameh, 2018). The growth of marketing performance in women's SMEs in the informal culinary sector in Bali is reflected in the measurement of research according to Limakrisna and Yoserizal (2016).

\section{Results}

\subsection{Characteristics of Respondents}

Respondent profiles were collected from six research areas consisting of one city and eight districts with 229 respondents in the province of Bali. It shows that the business actors where the business that had been run for more than 4 years (36.2\%) and less than 2 years $(34.5 \%)$, the remaining is between $3-4$ years; the average business actor is the owner himself $(93.1 \%$, the remaining $(6.9 \%)$ is running by someone else. The number of workers is mostly less than 3 people $(72.4 \%)$, between $4-6$ (22.4\%) and the remaining (5.2\%) are businesses that have more than 3 workers. Some $44.8 \%$ have a bachelor's level of education.

\subsection{Evaluation of the Outer Model Evaluation (measurement model)}

Testing the reliability construct using composite reliability (CR), average variable extracted (AVE), and alpha a (AVE) is 0.50 or more (Hair et al., 2014; Shrestha, 2021) are shown in Table 1.

Table 1

Test of the validity and reliability

\begin{tabular}{|c|c|c|c|c|c|}
\hline Variable & Dimension & Cronbach's Alpha & Composite Reliability & Average Variance Extracted (AVE) & Description \\
\hline \multirow{3}{*}{ Social Capital } & Structural & 0.8 & 0.9 & 0.7 & Valid \\
\hline & Relation & 0.8 & 0.9 & 0.7 & Valid \\
\hline & Cognitive & 0.8 & 0.9 & 0.7 & Valid \\
\hline \multirow{2}{*}{$\begin{array}{l}\text { Knowledge } \\
\text { Sharing }\end{array}$} & Tacit & 0.8 & 0.9 & 0.6 & Valid \\
\hline & Explicit & 0.9 & 0.9 & 0.8 & Valid \\
\hline \multirow[t]{4}{*}{ Innovation } & Product & 0.8 & 0.9 & 0.6 & Valid \\
\hline & Process & 0.7 & 0.8 & 0.6 & Valid \\
\hline & Market & 0.8 & 0.8 & 0.6 & Valid \\
\hline & Service & 0.7 & 0.8 & 0.6 & Valid \\
\hline \multicolumn{2}{|c|}{ Marketing Performance } & 0.8 & 0.9 & 0.6 & Valid \\
\hline
\end{tabular}

\subsection{Structural Model Test (Inner Model Evaluation))}

\subsubsection{The R Square ( $R^{2}$ test)}

As regards coefficient of determination or R-square, $\mathrm{R}^{2}$ shows the combination of the effects of exogenous variables on endogenous variables (Hair et al., 2014); as for the value $\mathrm{R}^{2}$, it is included in the weak model if the value is 0.25 . It is included 
in the moderate model if the value is 0.5; it is included in a strong model if the value is 0.75 (Hair et al., 2014). Zhang et al. (2017).) have a different opinion; a model is said to be strong if it has a value R2 of 0.67 , the model value is moderate if the value is 0.33 and the model is said to be weak if the model value is 0.19 . In this study, the value for R2 Service innovation has a value of 0.42 in the medium model, while the other variables have an R2 value between $0.693-0.865$, meaning that all variables fall into the strong category (Table 2).

Table 2

$\underline{\mathrm{R} \text {-square test results }}$

\begin{tabular}{lllll}
\hline Variable & Dimension & R Square & R Square Adjusted & 0.690 \\
\hline Social Capital & Structure & 0.693 & 0.864 & 0.791 \\
& Relation & 0.793 & 0.793 & 0.780 \\
Innovation & Cognitive & 0.795 & 0.791 \\
& Product & 0.782 & 0.413 \\
Knowledge Sharing & Process & 0.793 & 0.420 & 0.859 \\
& Marketing & 0.861 & 0.833 \\
Marketing Performance & Service & 0.835 & 0.773 \\
\hline
\end{tabular}

\subsubsection{Q-square (Predictive Relevance)}

The value of Q2 is between 0 and 1, where the value of Q2 is closer to the value of 1, the better the model. The criteria for the strength and weakness of the model measured by the value of Q2 are 0.35 (strong model), 0.15 (moderate model), and 0.02 (weak model) (Choshin \& Ghaffari, 2017).

\subsubsection{The Goodness of Fit (GoF)}

The GoF value can be calculated with the following formula using the data in Table 1 . The values are GoF 0.1 (weak), 0.25 (medium), and 0.36 (strong) (Choshin \& Ghaffari, 2017). The GoF test criteria are 0.1 (small GoF), 0.25 (medium GoF), and 0.36 (large GoF) (Tenenhaus et al., 2004). The overall evaluation research model can be expressed satisfactorily, so analysis can further proceed with hypothesis testing.

\section{Discussion}

Table 3

Hypothesis Result of the Structural Model

\begin{tabular}{|c|c|c|c|}
\hline Hypothesis & $\begin{array}{l}\text { Standardized } \\
\text { Coefficient }(\beta)\end{array}$ & t-value & Test Result \\
\hline $\mathrm{H}_{1}: \mathrm{MP} \leftarrow \mathrm{SC}$ & 0.088 & 1.093 & Not Supported \\
\hline $\mathrm{H}_{2}: \mathrm{KS} \leftarrow \mathrm{SC}$ & 0.619 & $9.794 * * *$ & Supported \\
\hline $\mathrm{H}_{3}: \mathrm{IN} \leftarrow \mathrm{SC}$ & 0.271 & $3.865 * * *$ & Supported \\
\hline $\mathrm{H}_{4}: \mathrm{IN} \leftarrow \mathrm{KS}$ & 0.637 & $10.28 * * *$ & Supported \\
\hline $\mathrm{H}_{5}: \mathrm{MP} \leftarrow \mathrm{KS}$ & 0.697 & $6.730 * * *$ & Supported \\
\hline $\mathrm{H}_{6}: \mathrm{MP} \longleftarrow \mathrm{IN}$ & 0.046 & 0.391 & Not Supported \\
\hline $\mathrm{H}_{7}: \mathrm{IN} \leftarrow \mathrm{KS} \leftarrow \mathrm{SC}$ & 0.509 & $7.979 * *$ & Supported \\
\hline $\mathrm{H}_{8}: \mathrm{MP} \leftarrow \mathrm{KS} \leftarrow \mathrm{SC}$ & 0.468 & $5.872 * * *$ & Supported \\
\hline $\mathrm{H}_{9}: \mathrm{MP} \leftarrow \mathrm{IN} \leftarrow \mathrm{KS}$ & 0.460 & 5.800 & Not Supported \\
\hline $\mathrm{H}_{10}: \mathrm{MP} \leftarrow \mathrm{IN} \leftarrow \mathrm{SC}$ & 0.405 & 3.662 & Not Supported \\
\hline
\end{tabular}

Table 3 shows that ten causal relationships between exogenous and endogenous variables have four insignificant relationships (hypothesis rejected) at $\alpha 0.05$ with a statistical value $<1.96$. There are four relationships between exogenous and endogenous variables, which are significant (hypothesis is accepted) at $\alpha 0.05$ with a statistical value $>1.96$. Based on the results of the direct relationship analysis from Table 3, H1, H6, H9 and H10 are rejected, whereas H2, H3, H4, H5, H7 and $\mathrm{H} 8$ are accepted.

\section{$\mathbf{H}_{1}$ : The Effect of Social Capital on Marketing Performance.}

The results of testing the influence of social capital and marketing performance show that social capital does not have a positive and significant effect. Social capital is something that cannot be relied on as a trigger for increased marketing performance. The results of this study mean that large relationship capital is not always able to improve marketing 
performance. Just having a lot of networks does not always make entrepreneurs fulfill their business goals. The results of this study are in line with research conducted by Akintimehin et al. (2019) that informal sector actors can only utilize internal resources, but external resources cannot be developed even though they already have strong social capital. Based on this explanation, it can be said that this study also confirms several studies including Akintimehin et al. (2019); Subramony et al. (2018); Kebede (2018); Farida et al. (2017). In informal women-run MSMEs in the culinary sector, the social capital they have tends to create gaps that support the performance of the business being run, the strong networks they have to monopolize certain parties or groups in increasing their business. Resources are not evenly distributed, only certain parties benefit so that trust and norms have not been formed so that a common vision and mission for creativity is not achieved; marketing performance in this case is also not achieved.

\section{H2: The Effect of Social Capital on Knowledge Sharing.}

The results of testing the effect of social capital on sharing knowledge indicate that social capital has a positive and significant effect on knowledge sharing. Social capital has a role in the exchange of useful information and knowledge in business, especially the informal sector. Tata and Prasad (2015); Allameh (2018) found the same results that structural, relational, and cognitive social capital gave positive results on knowledge sharing because it would improve intellectuality. The results of the study are in line with the research by Göksel and Aydıntan (2018) that all dimensions of social capital have a positive influence on knowledge sharing.

\section{$\mathbf{H}_{3}$ : The Effect of Social Capital on Innovation.}

The results of testing the effect of social capital on innovation show that social capital has a positive and significant effect on innovation. This means that having social capital will provide high ability to innovate. This study is in line with the research of Sanchez-Famoso et al. (2019) which states that social capital has a positive effect on innovation, and family social capital or non-family social capital has a positive effect, the joint effect is stronger in creating innovation. Relationships and cognition unite the vision and mission of a business that is guarded by norms to create creative innovation (Akhavan \& Mahdi Hosseini, 2015). Hau and Kang (2016); Agyapong et al. (2017); Acosta (2019) shows a positive influence between social capital and innovation, a positive relationship with social capital in business ties has a positive effect on the development of new product performance. The results of this study prove the importance of social capital in increasing the innovation of informal MSME actors in the culinary sector in Bali Province, because it creates innovations in both products and processes that require large resources, namely relationships.

\section{H4: The Effect of Knowledge Sharing on Innovation.}

The results of testing the effect of knowledge sharing on innovation show that knowledge sharing has a positive and significant effect on innovation. Knowledge-based theory, the supporting theory, can be said to be knowledgeable, highly individualistic and it is embedded in certain social contexts and even sharing knowledge simultaneously can affect the abilities and competencies of individuals and organizations and strengthen the intellectual capital of organizations in the field of human and organizational capital (Nonaka \& Takaeuchi, 1995; Van Dijk et al., 2016; Allameh, 2018). Hau and Kang (2016) also supports that knowledge can contribute to reducing production costs, faster completion of product processing, increased innovation in generating new product innovations and new service systems. The results of the research prove the sharing of knowledge on innovation in informal MSME women in the culinary sector in Bali province. Sharing knowledge that is carried out offline is also done by learning through workshops about new menus, which in turn will increase the ability of individuals or groups to create products with new preparations. Apart from this, sharing this knowledge is obtained directly during seminars or building motivation for innovation in oneself.

\section{H5: The Effect of Knowledge Sharing on Marketing Performance.}

The results of testing the effect of knowledge sharing on marketing performance show that knowledge sharing has a positive and significant effect on marketing performance. Sharing knowledge from Knowledge-based theory is divided into two dimensions, namely, tacit and explicit, where these two dimensions provide benefits with high-quality information in the form of knowledge and provide access to external resources (Tata \& Prasad, 2015). Rumanti et al. (2018; Salehzadeh et al. (2017) also provide the same opinion. The knowledge obtained by informal culinary women-run MSMEs from conducting workshops or oral stories between individuals is one of the strategies in cost savings. The knowledge gained by MSMEs provides changes in marketing systems and changes in an uncertain business environment to improve marketing performance.

\section{H6: The Effect of Innovation on Marketing Performance.}

The results of testing the effect of innovation on marketing performance show that innovation does not have a positive and significant effect on marketing performance. The research is in line with the research by Matsongoni and Mutambara (2018; García-Villaverde et al. (2018) that does not produce positive results because innovation takes a long time and the opportunity factor is very limited, especially for women who are unable to develop themselves and ultimately performance. The culinary 
business tends to use tools, for example, milk pie business actors, because the home scale still uses small-scale roasting tools where the production quantity is still low, using manual molds. Limitations in production methods mean that innovation does not have a positive impact on female SMEs in the informal culinary sector in Bali province.

\section{H7: The Role of Mediating Knowledge Sharing on Social Capital and Innovation.}

This study found that knowledge sharing mediates the effect of social capital on accepted innovation. This research is supported by Kim and Shim (2018) in the tourism industry sector, that sharing knowledge provides a positive feeling in building innovation. Knowledge sharing has a positive effect on three dimensions of social capital, which in turn provides an increase in innovation in the tourism sector (Harjanti \& Noerchoidah, 2017; Allameh, 2018). Informal women-run MSMEs in the culinary sector in Bali province are actors in a small-scale, home-based business with home capital. Human resources are the basic capital in responding to change, in addition to the role of social capital; there is the role of local wisdom that makes an individual cultured in sharing knowledge.

\section{H8: The Role of Mediating Knowledge Sharing on Social Capital and Marketing Performance.}

This study found that knowledge sharing mediates the effect of social capital on marketing performance. Social capital is an important component in improving marketing performance, with a strong network, norms, vision, and mission to create marketing performance among businesspeople, healthy competition will be formed. Knowledge sharing will create good marketing performance for business actors, especially female informal culinary MSMEs in the province of Bali.

\section{H9: The Role of Innovation Mediation on Social Capital and Marketing Performance.}

Innovation does not have a role in the relationship between social capital and marketing performance. This finding is in line with Dastourian et al. (2017); Subramoni et al. (2018); Sanchez-Famosos et al. (2019) that strong networks of social capital are unable to create creative ideas and are unable to improve sales. Other research supports this contention (Matsongoni \& Mutambara, 2018). Even though they have a dense network, the ability of everyone will be different in bringing about creative ideas to improve marketing performance. There are four dimensions in this research - product, process, marketing, and service. Innovation implementation still hits obstacles when faced with different situations. Product innovation increases the value of product quality, the selling power will increase, but this does not materialize in informal MSMEs because creativity in products experiences obstacles. In the process dimension, there is the adoption of production methods, the adoption of information, and the adoption of equipment, in innovation; changes must be made to the sophistication of production tools because one of the improvements in performance by using facilities and infrastructure is better, but for informal female culinary MSMEs, this is a very large problem, requiring many stakeholder roles.

\section{H10: Role of Innovation Mediation on Knowledge Sharing and Marketing Performance.}

Innovation mediation has no role in mediating knowledge sharing and marketing performance. These are different results from Afriyie (2019). Innovation has been understood as a significant antecedent of improving organizational performance in a competitive business environment. Sharing knowledge does not have a positive effect on the role of innovation; innovation is not able to bridge the marketing performance of informal women-run MSMEs in Bali Province. The use of innovation in mediating knowledge sharing does not increase women's culinary informal sector. Increased sales, creation of new markets, and even retaining old members as indicators of measuring the success of marketing performance are not possible in different situations.

\section{Conclusion}

Social capital and sharing of knowledge are proven to have a positive and significant effect on innovation and marketing performance, in micro-, small-, and medium-sized enterprises in the women-run informal culinary sector in Bali province. This means that these results indicate that the wider and stronger the network that is characterized with ethics and norms will create trust, the higher the marketing performance of the informal women MSMEs in the culinary sector in Bali province. Culinary business actors have structural social capital, where this social capital provides breadth to the relationship at the top level, government, or stakeholders other that makes it easier for business actors to obtain resources to improve performance. Relational and cognitive social capital will form mutual trust, maintain ethics and norms, the expectation of mutual reliance, shared assets, and vision and mission provide closeness and relationship and create capital relationships between individuals in the group, create a sense of togetherness, thus creating a mutually supportive business environment. It will be healthier, and progress in the vision and mission of the business will ultimately improve the marketing performance of female informal culinary MSMEs. Innovation is not proven to mediate the effect of knowledge sharing on knowledge sharing and marketing performance of informal culinary women MSMEs in Bali province. This means that innovation is not able to be implemented properly and so that it does not influence the relationship of knowledge sharing and marketing performance and is not able to improve marketing performance. 


\section{References}

Adi, N. R., Mulyadi, M., Setini, M., \& Astawa, N. D. (2021). Green Employee Empowerment? Driving and Inhibiting Factors for Green Employee Performance. Journal of Asian Finance, Economics and Business, 8(5), $293-302$. http://doi:10.13106/jafeb.2021.vol8.no5.0293

Aujirpongpan, S., \& Hareenin, Y. (2020). The effect of strategic intuition, business analytic, networking capabilities and dynamic strategy on innovation performance: The empirical study Thai processed food exporters. Journal of Asian Finance, Economics and Business, 7(1), 259-268. http://doi:10.13106/jafeb.2020.vol7.no1.259

Afriyie, S., Du, J., \& Musah, A. A. I. (2019). Innovation and marketing performance of SME in an emerging economy: the moderating effect of transformational leadership. Journal of Global Entrepreneurship Research, 9(1), 40. https://doi.org/10.1186/s40497-019-0165-3

Allameh, S. M. (2018). Antecedents and consequences of intellectual capital: The role of social capital, knowledge sharing and innovation. Journal of Intellectual Capital, 1469-1930. https://doi.org/10.1108/JIC-05-2017-0068

Akintimehin, O. O., Eniola, A. A., Alabi, O. J., Eluyela, D. F., Okere, W., \& Ozordi, E. (2019). Social capital and its effect on business performance in the Nigeria informal sector. Heliyon, 5(7), e02024. https://doi.org/10.1016/j.heliyon.2019.e02024

Akhavan, P., Hosseini, S. M., Abbasi, M., \& Manteghi, M. (2015). Knowledge-sharing determinants, behaviors, and innovative work behaviors: An integrated theoretical view and empirical examination. Aslib Journal of Information Management, 67(5), 562-591. https://doi.org/10.1108/AJIM-02-2015-0018

Acosta, P., Popa, S., \& Martinez-Conesa, I. (2018). Information technology, knowledge management and environmental dynamism as drivers of innovation ambidexterity: a study in SMEs. Journal of Knowledge Management, 22(4), 824-849. https://doi.org/10.1108/JKM-10-2017-0448

Agyapong, F. O., Agyapong, A., \& Poku, K. (2017). Nexus between social capital and performance of micro and small firms in an emerging economy: The mediating role of innovation. Cogent Business \& Management, 4(1), 1309784. https://doi.org/10.1080/23311975.2017.1309784

Bolisani, E., \& Bratianu, C. (2018). The emergence of knowledge management. In Emergent knowledge strategies (pp. 2347). Springer, Cham. DOI: 10.4018/jkm.2011070105

Burt, R. S. (1997). A note on social capital and network content. Social networks, 19(4), $355-373$. https://doi.org/10.1016/S0378-8733(97)00003-8

Boadu, F., Xie, Y., Du, Y. F., \& Dwomo-Fokuo, E. (2018). MNEs subsidiary training and development and firm innovative performance: The moderating effects of tacit and explicit knowledge received from headquarters. Sustainability, 10(11), 4208. https://doi.org/10.3390/su10114208

Choshin, M., \& Ghaffari, A. (2017). An investigation of the impact of effective factors on the success of e-commerce in smalland medium-sized companies. Computers in Human Behavior, 66, 67-74. https://doi.org/10.1016/j.chb.2016.09.026

Coleman, J. S. (1988). Social capital in the creation of human capital. American Journal of Sociology, 94, S95-S120.

Dean, H., Larsen, G., Ford, J., \& Akram, M. (2019). Female entrepreneurship and the metanarrative of economic growth: A critical review of underlying assumptions. International Journal of Management Reviews, 21(1), $24-49$. https://doi.org/10.1111/ijmr.12173

Dastourian, B., Kawamorita, K. H., Seyyed Amiri, N., \& Moradi, S. (2017). Women entrepreneurship: effect of social capital, innovation and market knowledge. AD-minister, 30, 115-130. https://doi.org/10.17230/ad-minister.30.6

Dhir, S., Rajan, R., Ongsakul, V., Owusu, R. A., \& Ahmed, Z. U. (2021). Critical success factors determining performance of cross-border acquisition: Evidence from the African telecom market. Thunderbird International Business Review, 63(1), 43-61. http://doi: 10.1002/tie.22156

Farida, N. (2017). Antecedent of innovation and marketing performance in the Batik industry. Advanced Science Letters, 23, 471-474. Doi:10.1166/asl.2017.7226

García-Villaverde, P. M., Rodrigo-Alarcón, J., Ruiz-Ortega, M. J., \& Parra-Requena, G. (2018). The role of knowledge absorptive capacity on the relationship between cognitive social capital and entrepreneurial orientation. Journal of Knowledge Management, 22(5), 1015-1036. https://doi.org/10.1108/JKM-07-2017-0304

Hair Jr, J., Sarstedt, M., Hopkins, L., \& G. Kuppelwieser, V. (2014). Partial least squares structural equation modeling (PLSSEM): An emerging tool in business research. European Business Review, 26(2), 106-121. https://doi.org/10.1108/EBR10-2013-0128.

Harjanti, D., \& Noerchoidah, N. (2017). The effect of social capital and knowledge sharing on innovation capability. Jurnal Manajemen dan Kewirausahaan, 19(2), 72-78. http://doi: 10.9744/jmk.19.2.72-78

Hau, Y. S., \& Kang, M. (2016). Extending lead user theory to users' innovation-related knowledge sharing in the online user community: The mediating roles of social capital and perceived behavioral control. International Journal of Information Management, 36(4), 520-530. https://doi.org/10.1016/j.ijinfomgt.2016.02.008

Göksel, A., \& Aydıntan, B. (2017). How can tacit knowledge be shared more in organizations? A multidimensional approach to the role of social capital and locus of control. Knowledge Management Research \& Practice, 15(1), 34-44.

Kebede, G. F. (2018). Social capital and entrepreneurial outcomes: Evidence from informal sector entrepreneurs in Ethiopia. The Journal of Entrepreneurship, 27(2), 209-242. https://doi.org/10.1177/0971355718781250 
Kim, N., \& Shim, C. (2018). Social capital, knowledge sharing and innovation of small- and medium-sized enterprises in a tourism cluster. International Journal of Contemporary Hospitality Management, 30(6), 2417-2437. doi: 10.1108/ijchm07-2016-0392

Kittikunchotiwut, P. (2020). The Roles of Organizational Learning Capability and Firm Innovation in the Relationship between Entrepreneurial Orientation and Firm Performance. Journal of Asian Finance, Economics and Business, 7(10), 651-661. http://doi:10.13106/jafeb.2020.vol7.no10.651

Kusumawardani, K. A., Widyanto, H. A., \& Deva, I. P. L. I. (2020).Understanding the Entrepreneurial Intention of Female Entrepreneurs in the Balinese Tourism Industry. International Journal of Research in Business and Social Science, 9, 6379. https://doi.org/10.20525/ijrbs.v9i1.611

Lee, W. S., \& Kim, B. Y. (2019). The effects of career orientations on entrepreneurial satisfaction and business sustainability. Journal of Asian Finance, Economics and Business, 6(4), 235-248. http://doi:10.13106/jafeb.2019.vol6.no4.235

Lee, S., Park, J.-G., \& Lee, J. (2015). Explaining knowledge sharing with social capital theory in information systems development projects. Industrial Management \& Data Systems, 115(5), 883-900. https://doi.org/10.1108/IMDS-01-20150017

Lee, J. C., Shiue, Y. C., \& Chen, C. Y. (2016). Examining the impacts of organizational culture and top management support of knowledge sharing on the success of software process improvement. Computers in Human Behavior, 54, $462-474$. https://doi.org/10.1016/j.chb.2015.08.030

Lefebvre, V. M., Sorenson, D., Henchion, M., \& Gellynck, X. (2016). Social capital and knowledge sharing performance of learning networks. International Journal of Information Management, 36(4), 570-579. http://dx.doi.org/10.1016/j.ijinfomgt.2015.11.008

Limakrisna, N., \& Yoserizal, S. (2016). Determinants of marketing performance: empirical study at National Commercial Bank in Jakarta Indonesia. SpringerPlus, 5(1), 1693. http://doi 10.1186/s40064-016-3362-3

Leal-Rodríguez, A. L., \& Albort-Morant, G. (2016). Linking market orientation, innovation and performance: An empirical study on small industrial enterprises in Spain. Journal of Small Business Strategy, 26(1), 37-50.

Lestari, S. D., Leon, F. M., Widyastuti, S., Brabo, N. A., \& Putra, A. H. P. K. (2020). Antecedents and consequences of innovation and business strategy on performance and competitive advantage of SMEs. Journal of Asian Finance, Economics and Business, 7(6), 365-378. http://doi:10.13106/jafeb.2020.vol7.no6.365

Martínez, L., Short, J. R., \& Estrada, D. (2017). The urban informal economy: Street vendors in Cali, Colombia. Cities, 66, 34-43. https://doi.org/10.1016/j.cities.2017.03.010

Matsongoni, H., \& Mutambara, E. (2018). An assessment of informal SMEs' potential in an African economy theoretical and conceptual framework. Public and Municipal Finance, 7(2). doi:10.21511/pmf.07(2).2018.01

Mintah, S., \& Darkwah, S. (2018). Drivers of Informal Sector Participation of Small and Medium Enterprise in Ghana. Scientia agriculturae bohemica, 49(1), 60-67. doi: 10.2478/sab-2018-0010

Mohajan Gemünden, H. G., Lehner, P., \& Kock, A. (2018). The project-oriented organization and its contribution to innovation. International Journal of Project Management, 36(1), $147-160$. https://doi.org/10.1016/j.ijproman.2017.07.009

Moqbel, M., \& Nah, F. F. H. (2017). Enterprise social media use and impact on performance: The role of workplace integration and positive emotions. AIS Transactions on Human-Computer Interaction, 9(4), 261-280. https://doi.org/10.17705/1thci.00098

Muafi, M. (2020). A nexus among strategic orientation, social network, knowledge sharing, organizational innovation, and MSMEs performance. Journal of Asian Finance, Economics and Business, 7(6), 327-338. doi:10.13106/jafeb.2020.vol7.no6.327

Muniady, R. A. L., Mamun, A. A., Mohamad, M. R., Permarupan, P. Y., \& Zainol, N. R. B. (2015). The effect of cognitive and relational social capital on structural social capital and micro-enterprise performance. Sage Open, 5(4), 2158244015611187.

Murphy, L., Huggins, R., Thompson, P. (2016). Social capital and innovation: A comparative analysis of regional policies. Environment and Planning C: Government and Policy, 34, 1025-57. http://doi: 10.1177/0263774X15597448

Nahapiet, J., \& Ghoshal, S. (1998). Social capital, intellectual capital, and the organizational advantage. Academy of Management Review, 23, 242-266. https://doi.org/10.5465/amr.1998.533225

Neumeyer, X., Santos, S. C., Caetano, A., \& Kalbfleisch, P. (2018). Entrepreneurship ecosystems and women entrepreneurs: A social capital and network approach. Small Business Economics, 53, 475-489. https://doi.org/10.1007/s11187-0189996-5

Nonaka, I., \& Takeuchi, H. (1995). The knowledge-creating company: How Japanese companies create the dynamics of innovation. Oxford: Oxford University Press.

Putra, I., Sunarsih, N., Novitasari, L., \& Setini, M. (2020). Exploring the relationship between social capital, innovation capability and innovation during the coronavirus pandemic. Uncertain Supply Chain Management, 8(4), 857-864. http://doi: 10.5267/j.uscm.2020.5.007

Rajapathirana, R. J., \& Hui, Y. (2018). Relationship between innovation capability, innovation type, and firm performance. Journal of Innovation \& Knowledge, 3(1), 44-55. https://doi.org/10.1016/j.jik.2017.06.002

Rass, M., Dumbach, M., Danzinger, F., Bullinger, A. C., \& Moeslein, K. M. (2013). Open innovation and firm performance: the mediating role of social capital. Creativity and innovation management, 22(2), $177-194$. https://doi.org/10.1111/caim.12028 
Rumanti, I. A., Hairmansis, A., Nugraha, Y., Susanto, U., Wardana, P., Subandiono, R. E., \& Kato, Y. (2018). Development of tolerant rice varieties for stress-prone ecosystems in the coastal deltas of Indonesia. Field Crops Research, 223, 75-82. https://doi.org/10.1016/j.fcr.2018.04.006

Sanchez-Famosoa, V., Pittinob, D, Chiricob, F., Masedaa, A., \& Iturraldea, T. (2019). Social capital and innovation in family firms: The moderating roles of family control and generational involvement. Scandinavian Journal of Management, 35(3), 1-13. https://doi.org/10.1016/j.scaman.2019.02.002

Salehzadeh, R., Pool, J. K., Mohseni, A. M., \& Tahani, G. (2017). Factors influencing organisational performance: the role of knowledge sharing and organisational agility. International Journal of Business Excellence, 11(3), 344-356. https://doi.org/10.1504/IJBEX.2017.081930

Shrestha, N. (2021). Factor analysis as a tool for survey analysis. American Journal of Applied Mathematics and Statistics, 9(1), 4-11. Http://doi:10.12691/ajams-9-1-2

Siqueira, A. C. O., Webb, J. W., \& Bruton, G. D. (2016). Informal Entrepreneurship and Industry Conditions. Entrepreneurship Theory and Practice, 40, 177-200. https://doi.org/10.1111/etap.12115

Smith, C. (2017). An Analysis Of Structural Social Capital And The Individual's Intention To Share Tacit Knowledge Using Reasoned Action Theory. Journal of Applied Business Research, 33, 475-88. http://dx.doi.org/10.1016/j.jbusvent.2016.10.003

Srisathan, W. A., Ketkaew, C., \& Naruetharadhol, P. (2020). The intervention of organizational sustainability in the effect of organizational culture on open innovation performance: A case of Thai and Chinese SMEs. Cogent business \& management, 7(1), 1717408. https://doi.org/10.1080/23311975.2020.1717408

Subramony, M., Segers, J., Chadwick, C., \& Shyamsunder, A. (2018). Leadership development practice bundles and organizational performance: The mediating role of human capital and social capital. Journal of Business Research, 83, 120-129. http://dx.doi.org/10.1016/j.jbusres.2017.09.044

Susilo, W. H. (2016). An Impact of Behavioral Segmentation to Increase Consumer Loyalty: Empirical Study in Higher Education of Postgraduate Institutions at Jakarta. Procedia - Social and Behavioral Sciences, $229,183-195$. https://doi.org/10.1016/j.sbspro.2016.07.128

Torres, A. P., Marshall, M. I., \& Sydnor, S. (2019). Does social capital pay off? The case of small business resilience after Hurricane Katrina. Journal of Contingencies and Crisis Management, 27(2), 168-181. http://dx.doi.org/10.1016/j.jbusres.2017.05.029

Tata, J., \& Prasad, S. (2015). Immigrant family businesses: social capital, network benefits and business performance. International Journal of Entrepreneurial Behavior \& Research, 21(6), 842-866. http://doi: 10.1108/IJEBR-06-2014-0111.

van Dijk, A., Hendriks, P., \& Romo-Leroux, I. (2016). Knowledge sharing and social capital in globally distributed execution. Journal of Knowledge Management, 20(2), 327-343. https://doi.org/10.1108/JKM-07-2015-0268

Zhang, D., Zhang, F., Lin, M., \& Du, H. S. (2017). Knowledge sharing among innovative customers in a virtual innovation community: The roles of psychological capital, material reward and reciprocal relationship. Online Information Review, 41(5), 691-709. https://doi.org/10.1108/OIR-08-2016-0226

Zhou, J., Mavondo, F. T., \& Saunders, S. G. (2019). The relationship between marketing agility and financial performance under different levels of market turbulence. Industrial Marketing Management, 83, 31-41. https://doi.org/10.1016/j.indmarman.2018.11.008

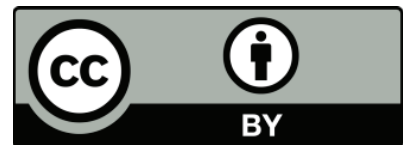

(C) 2021 by the authors; licensee Growing Science, Canada. This is an open access article distributed under the terms and conditions of the Creative Commons Attribution (CC-BY) license (http://creativecommons.org/licenses/by/4.0/). 